\title{
The Dynamics of $\mathrm{C}$ and $\mathrm{N}$ by Combination of Composted Fresh Organic Waste as Soil Amendment in the Soil Thickness at Pineapple Plantation, Lampung Indonesia
}

\author{
Susila Herlambang ${ }^{\#}$, Azwar Maas ${ }^{*}$, Sri Nuryani Hidayah Utami ${ }^{*}$, Jaka Widada $^{+}$ \\ \# Department of Soil Science, Universitas Pembangunan Nasional Veteran Yogyakarta, Yogyakarta, Indonesia \\ E-mail: susilaherlambang@upnyk.ac.id \\ *Department of Soil Science, Universitas Gadjah Mada, Yogyakarta, Indonesia \\ E-mail: azwar.maas@gmail.com; nuryani@ugm.ac.id \\ ${ }^{+}$Department of Soil Mycrobiologi, Universitas Gadjah Mada, Yogyakarta, Indonesia \\ E-mail: jwidada@gmail.com
}

\begin{abstract}
The purpose of the research was to study the effect of decomposition of fresh organic waste on improvement of soil nutrients, especially the presence carbon avalability at soil surface layer. The study was conducted to evaluate the decomposition progress of fresh organic waste and canned pineapple waste on Ultisol Lampung. The experiment was designed with a completely randomized factorial design with two factors: the first was fresh organic waste (200 ton.ha-1 chopper pineapple crops, 40 ton.ha ${ }^{-1}$ cattle manure, 40 ton.ha ${ }^{-1}$ cassava waste, 40 ton.ha ${ }^{-1}$ waste pump pineapple, 2 ton.ha ${ }^{-1}$ mill juice pineapple), and the second was thickness on the top layer (i.e. $0-15 \mathrm{~cm}, 0-30 \mathrm{~cm}$ and $0-45 \mathrm{~cm}$ ), the each repeated 3 replication so total treatments were 24 plot pots. The results showed that the fresh organic waste and canning pineapple waste application can increase the resistance carbon and nitrogen on the soil. The more thickness of soil indicate to the more decrease of $\mathrm{C}, \mathrm{N}, \mathrm{C} / \mathrm{N}$ ratio. The thickness of the soil $0-15 \mathrm{~cm}$ of $\mathrm{C}$ loss above $60 \%, 0-30 \mathrm{~cm}$ loss of $\mathrm{C}$ is less than $30 \%$ and less than $20 \%$ loos $\mathrm{C}$-organic for $0-45 \mathrm{~cm}$. The $\mathrm{N}$ loss less than $50 \%$ on 0-15 $\mathrm{cm}$, and less than $40 \%$ for $0-30$ and $0-45 \mathrm{~cm}$. Fresh organic matter decomposition rate in the near of top soil more faster than subsoil. The thickness of $0-45 \mathrm{~cm}$ it showed very low total carbon whiches affected to the the value of the $\mathrm{C} / \mathrm{N}$, It smaller than $\mathrm{C} / \mathrm{N}$ ratio on the soil thickness above. Its because the process of decomposition of fresh organic matter mixed with mineral soil becomes slower. The innovation of technology that applied to combination on soil thickness with organic waste and canning pineapples can increase avalability of carbon and soil nutrients at Ultisol Lampung. It is an important aspect to improve soil fertility.
\end{abstract}

Keywords — decompositition; fertility; fresh organic matter; soil amendment.

\section{INTRODUCTION}

The decline in soil health and soil quality can be caused by the imbalance of soil nutrients, excessive fertilization, soil pollution and soil loss processes [1], [2]. The low soil nutrients in pineapple plantations Lampung, Indonesian cause weight biomass resulting becomes less than optimal, the fruit production is low ( $<75$ tons/ha). The purpose of this research to know the effect decomposition of soil amandement for enrichment $\mathrm{C}$-organic in one cropping cycle. Enriching soil $\mathrm{C}$ through the recycling of organic wastes provides beneficial ecosystem services such as nutrient recycling [3], and improving soil quality [4]. The nutrients doesnt enought in the soil because the nutrients uptake by plant and leach in the soil getting major problem for management old soil such as on Ultisol. The incorporation of fresh organic matter to the soil can be used an alternative to improve soil health. The decomposition of organic waste products aimed at improving the availability of C-organic and nutrients on Ultisol Lampung. Processing of fresh organic matter by mixing these materials into mineral of soil $(0-45 \mathrm{~cm})$ would be easily degraded by soil microbes, so it will increase soil aggregate stability, nutrient cycling, and microbial activity [5].

The Carbon in deep soil layers protected from decomposition due to the lack of fresh plant residues to stimulate microbial activity [6]. Soil carbon accumulation is determined by the addition and loss of carbon in the soil. The low of $\mathrm{C}$ in the soil is major problem in fertility and soil quality [7], [8]. The contents of soil $\mathrm{C}$ and $\mathrm{N}$ total $\mathrm{C}$, total $\mathrm{N}$, 
soluble organic $\mathrm{C}$, soluble $\mathrm{N}$ and microbial biomass $\mathrm{C}$ in the O horizon were the largest [9], [10]. The content of $\mathrm{C}$ in the soil is very unstable due to the volatile and leached. Percentage loss of C-organic relative large so resistance of $\mathrm{C}$ fast disappear in a few periode. Additional $\mathrm{C}$ inputs are introduced to subsurface soil from upper soil layers via water transport of dissolved and particulate organic $\mathrm{C}$ and bio-turbation [11], [12], [13], [14]. The added organic matters showed quite different $\mathrm{C}$ and $\mathrm{N}$ dynamics during decomposition in soil due to a high $\mathrm{C} / \mathrm{N}$ ratio, the initial immobilization of $\mathrm{N}$ occurred prior to an increase inmineral $\mathrm{N}$ generation.

The utilization of various kind of organic waste materials and combination is an effort to find solutions for increasing fertility, soil health and quality. The decomposition rate of each type of organic matter will affect of rate decomposition process by microbes in the soil, the high lignin material will slower the microorganisms to decompose organic matter. The addition of plant residues also significantly increased amended soil microbial biomass $\mathrm{C}$ and N. Organic waste management plant pineapples in the crop cycle is to supplied the $\mathrm{C}$ into the soil along with soil nutrients. The application of innovation and technology with the application of soil management organic waste is an important aspect to improve fertility.

\section{MATERIAL AND METHOD}

Soil samples were collected from Ultisol at PT Great Giant Pineapple Lampung Indonesia, the ordinate $4^{0} 49^{\prime} 07^{\prime}$ ' $\mathrm{S}$ dan $105^{\circ} 13$ ' 13 ' 'E altitute 46 OSL. The organic waste for decomposition in the dephts of soil were cattle manure, cassava waste, pump waste (bromelin), chopper pineapple crops, and mill pineapple juice.

Soil sampling was carried out on soil layer of $0-15 \mathrm{~cm}$ (T1), 0-30 cm (T2) and 0-45 cm (T3) in pineapple plantation Lampung Indonesia. Organic waste input is $\mathrm{K} 1$ : chopper pineapple crops 200 tonnes per hectare, K2: chopper pineapple crops 200 tonnes per hectare + cattle manure (solid) 40 tonnes per hectare + mill juice pineapple 2 tonnes per hectare + cattle manure (liquid) 2 tonnes per hectare, K3: chopper pineapple crops 200 tonnes per hectare + cassava waste 40 tonnes per hectare + pineapple pump waste (bromelin) 40 tonnes per hectare + mill juice pineapple 2 tonnes per hectare + cattle manure (liquid) 2 tonnes per hectare. The fresh organic waster mixed in the soil thickness of 0-15 cm (T1); 0-30 cm (T2); and 0-45 cm (T3) which was decomposed in the volume of $1.65 \mathrm{~cm} \times 1.65 \mathrm{~cm} \times 55 \mathrm{~cm}$ depth in lysimeter system. The study design was done using the dependent variable treatment analysis of variance with $\mathrm{F}$ test confidence $5 \%$, if there was any significant difference between the treatment then was tested by Duncan's Multiple Range Test at $5 \%$.

\section{RESULT AND DISCUSSION}

The Ultisol Lampung has low $\mathrm{C}$-organic and $\mathrm{C} / \mathrm{N}$ ratio on the various depths. The pineapple plantations have many source of waste that can be used as a source of organic matter and nutrients in soil (Table. 1).

The application of fresh organic waste mixed with clay mineral in various thickness in to soil is expected to increase $\mathrm{C}$-organic. The $\mathrm{C}$ concentration of the crop residues ranged from $44.9 \%$ to $49.1 \%$ and $\mathrm{N}$ concentration ranged from $0.316 \%$ to $3.88 \%$, resulting in a wide range in $\mathrm{C} / \mathrm{N}$ ratios about 12-14 [15]. The addition of fresh organic matter ameliorant mixing technique with fresh organic matter into the soil is one of the techniques of land management to maintain soil organic carbon.

Soil amendments on mill juice, cattle manure and pineapple pump waste (bromelin) as a source of organic carbon is higher than chopper pineapple crop and cassava waste (Table. 1). The mixed application of fresh waste materials and clay minerals are expected to contribute positively to the value of organic carbon and plants nutrient.

The addition of fresh organic matter are easily degraded by soil microbial population that lead to an increase in nutrient cycling and increase microbial activity [16]. The ameliorant application of cattle manure (solid) to increased C-organic higher than application of chopper pineapple crops 200 tonnes per hectare (K1) and chopper pineapple crops 200 tonnes per hectare + cassava waste 40 tonnes per hectare + pineapple pump waste (bromelin) 40 tonnes per hectare + mill juice pineapple 2 tonnes per hectare + cattle manure (liquid) 2 tonnes per hectare (K3).

Differences raw materials type will influence the process of of organic matter decomposition in soil, thus it will determine the amount of C-organic availability in soil. The application of fresh waste material in the canning pineapple waste increase the levels of C-organic $0.5-1 \%$ on Ultisol Lampung.

TABLE I

Characteristic of Fresh Organic Waste at Pineapple Plantation Indonesia

\begin{tabular}{|c|c|c|c|c|c|c|c|c|c|}
\hline \multirow[b]{2}{*}{ Kind of analysis } & \multicolumn{3}{|c|}{ Soil thickness (cm) } & \multirow{2}{*}{$\begin{array}{l}\text { Chopper } \\
\text { pineapple } \\
\text { crops }\end{array}$} & \multirow{2}{*}{$\begin{array}{c}\text { Cassava } \\
\text { waste }\end{array}$} & \multirow{2}{*}{$\begin{array}{l}\text { Pump waste } \\
\text { (Bromelain) }\end{array}$} & \multicolumn{2}{|c|}{ Cattle manure } & \multirow{2}{*}{$\begin{array}{l}\text { Mill } \\
\text { juice }\end{array}$} \\
\hline & $0-15$ & $0-30$ & $0-45$ & & & & Solid & Liquid & \\
\hline C-Organic (\%) & 1.00 & 1.01 & 0.94 & 27.35 & 13.91 & 29.64 & 31.34 & 0.88 & 35.05 \\
\hline Organic Matter (\%) & 1.72 & 1.73 & 1.62 & 47.03 & 23.92 & 50.99 & 53.90 & 1.52 & 60.28 \\
\hline Total N (\%) & 0.14 & 0.13 & 0.13 & 1.13 & 0.34 & 1.02 & 3.31 & 1.21 & 3.14 \\
\hline $\mathrm{C} / \mathrm{N}$ & 7.21 & 7.68 & 7.32 & 24.28 & 40.79 & 29.04 & 9.48 & 21.13 & 11.17 \\
\hline $\mathrm{pH} \mathrm{H} \mathrm{H}_{2} \mathrm{O}$ & 4.17 & 4.15 & 4.43 & 5.60 & 7.00 & 4.75 & 7.18 & 8.34 & 3.44 \\
\hline
\end{tabular}

Numbers in thesame column followed by similar letters are not significantly different according to Duncan's Multiple range test (P $>0.05)$. 
TABLE II

The Analysis Of C-Organic AND N AFTER APLiCATIOn Of SoIL AMENDMENTS

\begin{tabular}{|c|c|c|c|c|c|c|c|c|}
\hline \multirow{2}{*}{ Soil Treatment } & \multicolumn{4}{|c|}{ C-Organic (\%) } & \multicolumn{4}{|c|}{$\mathbf{N}(\%)$} \\
\hline & 0 month & 1 month & 2 month & 3 month & 0 month & 1 month & 2 month & 3 month \\
\hline T1K1 & $1.36^{\mathrm{bc}}$ & $1.49^{\mathrm{de}}$ & $1.80^{\mathrm{bcd}}$ & $2.05^{\mathrm{b}}$ & $0.15^{\text {cdef }}$ & $0.12^{\mathrm{h}}$ & $0.18^{\mathrm{a}}$ & $0.17^{\mathrm{c}}$ \\
\hline T2K1 & $1.34^{\mathrm{c}}$ & $1.58^{\mathrm{bc}}$ & $1.72^{\text {efg }}$ & $1.66^{\mathrm{fg}}$ & $0.13^{\mathrm{ef}}$ & $0.14^{\mathrm{fg}}$ & $0.16^{\mathrm{b}}$ & $0.14^{\mathrm{fg}}$ \\
\hline T3K1 & $1.29^{\mathrm{cd}}$ & $1.39^{\mathrm{g}}$ & $1.50^{\mathrm{i}}$ & $1.56^{\mathrm{h}}$ & $0.15^{\text {cdef }}$ & $0.14^{\mathrm{fg}}$ & $0.15^{\mathrm{c}}$ & $0.12^{\mathrm{h}}$ \\
\hline T1K2 & $1.56^{\mathrm{a}}$ & $1.68^{\mathrm{a}}$ & $1.68^{\mathrm{fg}}$ & $1.96^{\mathrm{cd}}$ & $0.19^{\mathrm{a}}$ & $0.16^{\mathrm{e}}$ & $0.17^{\mathrm{a}}$ & $0.15^{\text {def }}$ \\
\hline T2K2 & $1.37^{\mathrm{bc}}$ & $1.48^{\mathrm{def}}$ & $1.75^{\text {cde }}$ & $1.75^{\mathrm{e}}$ & $0.15^{\text {cdef }}$ & $0.15^{\mathrm{f}}$ & $0.17^{\mathrm{a}}$ & $0.15^{\text {efg }}$ \\
\hline T3K2 & $1.43^{\mathrm{b}}$ & $1.62^{\mathrm{abc}}$ & $1.67^{\mathrm{g}}$ & $1.62^{\mathrm{g}}$ & $0.14^{\mathrm{ef}}$ & $0.14^{\mathrm{fg}}$ & $0.16^{\mathrm{b}}$ & $0.12^{\mathrm{h}}$ \\
\hline $\mathrm{T} 1 \mathrm{~K} 3$ & $1.23^{\mathrm{c}}$ & $1.44^{\mathrm{efg}}$ & $1.80^{\mathrm{bc}}$ & $1.98^{\mathrm{c}}$ & $0.15^{\text {cdef }}$ & $0.21^{\mathrm{c}}$ & $0.13^{\text {ef }}$ & $0.19^{b c}$ \\
\hline $\mathrm{T} 2 \mathrm{~K} 3$ & $1.30^{\mathrm{cd}}$ & $1.42^{\mathrm{g}}$ & $1.69^{\mathrm{fg}}$ & $1.67^{\mathrm{f}}$ & $0.13^{\mathrm{f}}$ & $0.24^{\mathrm{a}}$ & $0.12^{\mathrm{g}}$ & $0.15^{\mathrm{de}}$ \\
\hline T3K3 & $1.31^{\mathrm{cd}}$ & $1.17^{\mathrm{ij}}$ & $1.56^{\mathrm{h}}$ & $1.53^{\mathrm{h}}$ & $0.15^{\text {cdef }}$ & $0.20^{\mathrm{cd}}$ & $0.14^{\mathrm{de}}$ & $0.16^{\mathrm{d}}$ \\
\hline
\end{tabular}

Numbers in the same column followed by similar letters are not significantly different according to Duncan's Multiple range test (P $>0.05)$.

T1: soil thickness 0-15 cm, T2: soil thickness 0-30 cm, T3: soil thickness 0-45 cm,

$\mathrm{K} 1$ : chopper pineapple crops 200 ton $\mathrm{ha}^{-1}$,

K2: chopper pineapple crops 200 ton $\mathrm{ha}^{-1}+$ cattle manure (solid) 40 ton ha ${ }^{-1}+$ mill juice pineapple 2 ton ha ${ }^{-1}+$ cattle manure (liquid) 2 ton $\mathrm{ha}^{-1}$,

K3: chopper pineapple crops 200 ton $\mathrm{ha}^{-1}+$ cassava waste 40 ton $\mathrm{ha}^{-1}+$ pineapple pump waste (bromelin) 40 ton $\mathrm{ha}^{-1}+$ mill juice pineapple 2 ton $\mathrm{ha}^{-1}+$ cattle manure (liquid) 2 ton $\mathrm{ha}^{-1}$

Fresh organic matter decomposition rate in the near of top soil more faster than subsoil, the result of $\mathrm{C}$-organic on the thickness $0-15 \mathrm{~cm}$ is higher on the all treatment fresh organic waste application of chopper pineapple crops 200 tonnes per hectare (K1); the application of chopper pineapple crops 200 tonnes per hectare + cattle manure (solid) 40 tonnes per hectare + mill juice pineapple 2 tonnes per hectare + cattle manure (liquid) 2 tonnes per hectare (K2) and the aplication of chopper pineapple crops 200 tonnes per hectare + cassava waste 40 tonnes per hectare + pineapple pump waste (bromelin) 40 tonnes per hectare + mill juice pineapple 2 tonnes per hectare + cattle manure (liquid) 2 tonnes per hectare (K3) (Fig. 1).

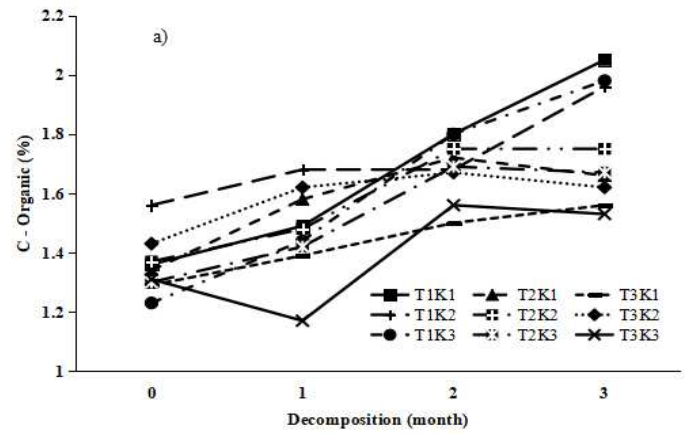

Fig. $1 \mathrm{C}$-organic on the decomposition of fresh organi waste at pineapple plantation

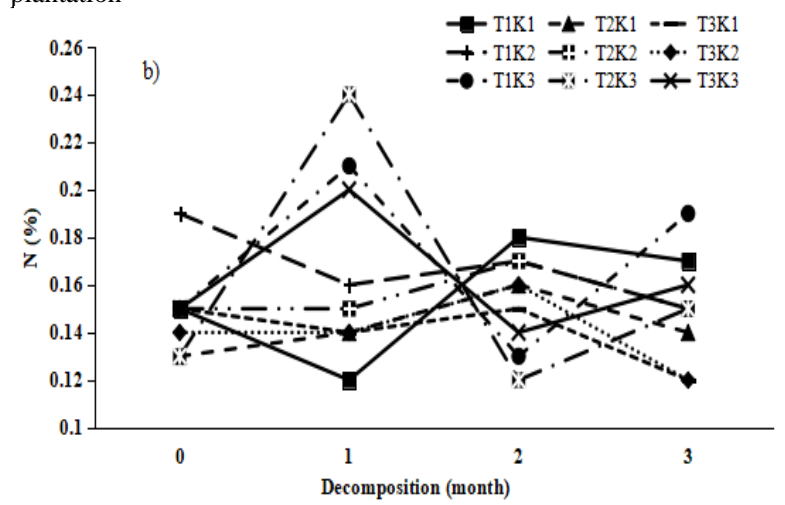

Fig. $2 \mathrm{~N}$ total on the decomposition of fresh organic waste at pineapple plantation
The total carbon retained in deeper soil layers might be more stable than in the soil surface, due to differences in source, composition, and environmental conditions [15], [16]. The statistical test showed that there were significant differences $5 \%$ level on soil organic carbon in the terms of treatments (Table. 2). Soil organic carbon which was incubated three months at lysimeter system increased with increasing rate of amendments, and tend to decline with depth of soil.

The ameliorant of formulations fresh waste pineapple cannery increased the availability of organic carbon. The carbon content increased about more than $2 \%$ at depth of 0 $15 \mathrm{~cm}$ (T1). At the soil subsurface the organic carbon content was higher than in the deeper, due to faster decomposition process of waste materials on soil surface influenced by the presence of aeration. Fresh organic waste that mixed with mineral soil, was relatively more susceptible to weathering and leaching, thus the level of organic carbon decline up to $0.74 \%$ (Table 2). The actual and potential soil organic carbon decreased with depth of fresh organic waste in the soil, the soil with in deeper layers had lower soil organic content than above layer (Figure 3 ).

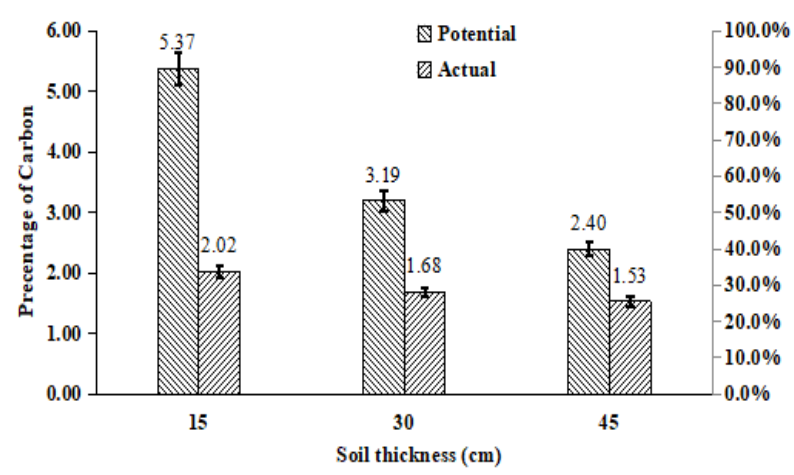

Fig. 3 Actual and potential soil organic carbon mixed on soild depths after 3 month

The carbon organic content of soil was higher on the top soil than deeper, because the aeration on the top soil higher than in the deeper. The waste matterial which are have 
hightly decomposition rate as soil carbon source. The content of potential C-organic from fresh waste material formulation was sufficient (> $2 \%$ ), and the actual of $\mathrm{C}$ organic content after three month decomposition was more than $1.5 \%$ (Fig. 2).

The incorporation of fresh organic wastes and canning pineapple waste is important to supply the avaibility of carbon and nitrogen. The nitrogen was higher in application of chopper pineapple crops 200 tonnes per hectare (K1) and the aplication of chopper pineapple crops 200 tonnes per hectare + cassava waste 40 tonnes per hectare + pineapple pump waste (bromelin) 40 tonnes per hectare + mill juice pineapple 2 tonnes per hectare + cattle manure (liquid) 2 tonnes per hectare $(\mathrm{K} 3)$ on the top soil $(0-15 \mathrm{~cm})$ but the application of chopper pineapple crops 200 tonnes per hectare + cattle manure (solid) 40 tonnes per hectare +mill juice pineapple 2 tonnes per hectare + cattle manure (liquid) 2 tonnes per hectare $(\mathrm{K} 2)$ relative same on the thickness 0-15 $\mathrm{cm}$ (T1) and 0-30 cm (T2), aeration and differences of organic matter is very important for the decomposition (Figure 1). To according [17], the availability of total carbon which increased at $0-15 \mathrm{~cm}$ and $15-30 \mathrm{~cm}$, but not at the $30-$ $45 \mathrm{~cm}$ in depth. It is probably of the translocation deeper soil layers. There was big lost of organic carbon, mostly at surface depth $(0-15 \mathrm{~cm})$, and less lost of organic carbon with deeper depth layer $(0-30 \mathrm{~cm}$ and $0-45 \mathrm{~cm}$. The percentage of organic carbon loss in the soil depth is large due to gas emission and leaching.

\section{A. Nitrogen and $C: N$ ratio}

Total nitrogen on the soil in the all application did not show significantly difference according to Duncan's Multiple range test $(\mathrm{P}>0.05)$ (Table 2). The addition of organic matter into the soil, affect greatly on nitrogen supply in soil [18]. Total $\mathrm{N}$ in Ultisol was increase at in application of chopper pineapple crops 200 tonnes per hectare (K1) from $0.12-0.13 \%$ to $0.12-0.22 \%$ (Table. 1 and Table. 2), due to the contribution of different component of organic waste materials mainly from cattle manure $(3.31 \% \mathrm{~N})$ and mill juice materials $3.14 \%$ (Table. 1). The process of decomposition in soil by microorganisms activity requires $\mathrm{N}$, so that there will be a reduction of $\mathrm{N}$ in the soil. At the beginning of the decomposition process the nitrogen relative decreased, because nitrogen was used by microorganism but eventually the nitrogen returned to the soil by the process of immobilization. After further decomposition of organic matter, the soil nitrogen increased on 2 and 3 month (Table. 2). After three months decomposition process, the application of chopper pineapple crops 200 tonnes per hectare + cattle manure (solid) 40 tonnes per hectare + mill juice pineapple 2 tonnes per hectare + cattle manure (liquid) 2 tonnes per hectare (K2) and the aplication of chopper pineapple crops 200 tonnes per hectare + cassava waste 40 tonnes per hectare + pineapple pump waste (bromelin) 40 tonnes per hectare + mill juice pineapple 2 tonnes per hectare + cattle manure (liquid) 2 tonnes per hectare (K3) improved the soil nitrogen levels $(>0.07 \%)$ in the lysimeter system (Table. 2). The decreasing nitrogen content in lysimeter system is possible due to the high mobility of nitrogen, the nitrogen was dissolved and lost by leaching process. After three month decomposition, showed higher level actual and potential soil nitrogen than the soil of control, this was likely raw decomposed material with a layer of soil capable of providing $\mathrm{N}$ relative adequacy in quantities.

The depth of soil in $0-15 \mathrm{~cm}$ nitrogen loss was about $46.81 \%, 39.88 \%$ loss at $0-30 \mathrm{~cm}$, and $35.88 \%$ loss at depth $0-45 \mathrm{~cm}$ (Fig. 4). The $\mathrm{C} / \mathrm{N}$ ratio, widely used to determine the degree of maturity of the organic matter of wastes, is a suitable index for materials which do not contain sewage sludge [19].

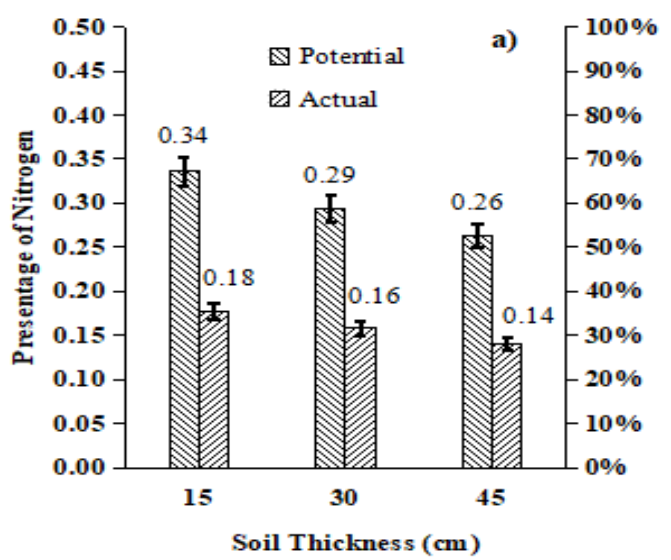

Fig. 4 Actual and potential nitrogen analysis at different soil depths after three month

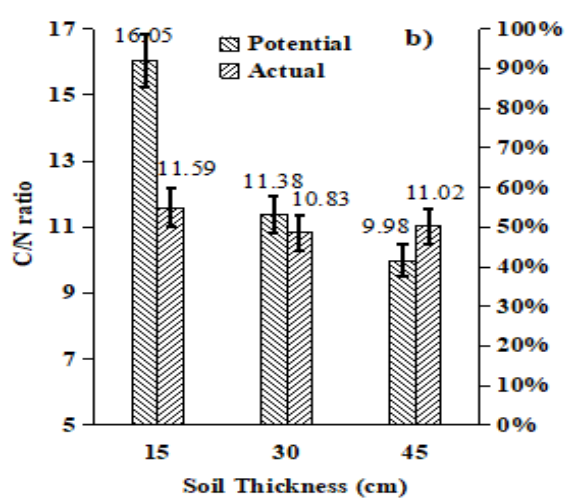

Fig. 5 Actual and potential $\mathrm{C} / \mathrm{N}$ ratio at different soil depths after three month

The raw material was decomposed of fresh organic waste in soil which transformation to be soil humus could make better $\mathrm{C} / \mathrm{N}$ ratio in soil, hence influence to plant growth. In upland soils with a relatively low amount of labile organic $\mathrm{N}$, the mineralization could be regulated by the amount of labile organic C instead of $\mathrm{N}$ [20]. Potential $\mathrm{C} / \mathrm{N}$ ratio was relatively higher than actual $\mathrm{C} / \mathrm{N}$ ratio at soil dephts of more than $30 \mathrm{~cm}$ (Fig. 5), it is probably due to different $\mathrm{C}$ content that produce by different raw materials. The more ripe the compost material, the easier it is to decomposed, thus the $\mathrm{C}$ content could be released, but the $\mathrm{C}$ resistance also low, and make it easier to loss as gas emission. Increased $\mathrm{C}$ soil depends on biomass accumulation, especially at the type of biomass and the length of decomposition process [21]. To degraded organic compounds, microorganism convert 60$70 \%$ of carbon dioxide and use the remaining $30-40 \%$ of their body as cell component of the cell [22]. The result of actual $\mathrm{C} / \mathrm{N}$ ratio was still above control (7.69) at soil 
thickness more than $30 \mathrm{~cm}$, it means that the application of chopper pineapple crops 200 tonnes per hectare + cattle manure (solid) 40 tonnes per hectare + mill juice pineapple 2 tonnes per hectare + cattle manure (liquid) 2 tonnes per hectare (K2) and the aplication of chopper pineapple crops 200 tonnes per hectare + cassava waste 40 tonnes per hectare + pineapple pump waste (bromelin) 40 tonnes per hectare + mill juice pineapple 2 tonnes per hectare + cattle manure (liquid) 2 tonnes per hectare (K3) could increase the $\mathrm{C} / \mathrm{N}$ ratio in the soil. The potential $\mathrm{C} / \mathrm{N}$ ratio decreased after three months decomposition of raw materials, actual $\mathrm{C} / \mathrm{N}$ ratio also decrease, because the soil organic carbon was not stable in soil.

\section{CONCLUSIONS}

The application of soil amendments by mixing into clay minerals is an effective decomposition process in stabilizing carbon soil. The innovation of technology with combining in the soil in dephts with organic waste to improve fertility, health and quality of soil. The carbon, nitrogen release and $\mathrm{C} / \mathrm{N}$ ratio are depending to organic material. The carbon loss more than $60 \%$ at soil thickness $0-15 \mathrm{~cm}$, less than $30 \%$ at soil thickness $0-30 \mathrm{~cm}$, and less than $20 \%$ on soil thickness $0-45 \mathrm{~cm}$. At soil thickness of $0-15 \mathrm{~cm}$, and the nitrogen loss less than $50 \%$ and depht $0-30$ and $0-45 \mathrm{~cm}$ are nitrogen losses less than $40 \%$. The general availability of $\mathrm{C}, \mathrm{N}$ and $\mathrm{C} / \mathrm{N}$ ratio is determined by the quality of the organic material decomposes, especially the kinds of material that mixed into the thickness of soil.

\section{ACKNOWLEDGMENT}

This research was supported by PT. Great Giant Pineapple Lampung Indonesia.

\section{REFERENCES}

[1] Baglieri A.A, Ioppolo, M. Ne`gre, and M. Gennari, "A method for isolating soil organic matter after the extractionof humic and fulvic acids," Organic Geochemistry., vol. 38, pp. 140-150, Jan. 2007.

[2] Zhang W.L, Tian Z.X, Zhang N, Li X.Q, "Nitrate pollution of groundwater in northern China," Agriculture Ecosystem Environment., vol. 59, pp. 223-231, Oct. 1996.

[3] Fontaine S, S. Barot, P. Barre, N. Bdjouj, B. Mary, and C. Rumpel, "Stability of organic carbon in deep soil layers controlled by fresh carbon supply," Nature., vol. 450, pp. 277-280. Nov . 2007.

[4] Gomez K.A, and A.A. Gomez, Statistical Procedures for Agricultural Research, 2nd ed. New York: John Willey and Sons, 1993.

[5] Gugino B.K, O.J. Idowu, R.R. Schindelbeck, H.M Van Es, D.W. Wolfe, B.N. Moebius Clune, J.E. Thies, and G.S. Abawi, Cornell Soil Health Assesment Training Manual, 2nd ed. New York: Cornell University, 2009.
[6] Li, P., Lu J, Wang Y, Wang, S, Hussain S, Ren T, Li X, "Nitrogen losses, use efficiency and productivity of early rice under controlled release urea," Agriculture Ecosystems and environment., vol. 251, pp. 78-87. Jan. 2018."

[7] Li Z, Liu C, Dong Y, Chang X, Nie X, Liu L, Zeng G, "Response of soil organic carbon and nitrogen stocks to soil erosion and land use types in the losses hilly gully region of China," Soil and tillage usage., vol. 166, pp. 1-9. March. 2017.

[8] Obu J, Lantuit H, Myers Smith, I. Heim, B. Wolter J, and Fritz M, "Effect of terrain characteristic on soil organic carbon and total nitrogen stocks in soils of Herschel island, western Canadian arctic," Geomorphic disturbance., vol. 28. pp. 92-107. Sep. 2017.

[9] Finney D.M, White C.M, and Kaye J.P, "Biomass production and carbon/nitrogen ratio influence ecosystem services cover crop mixtures," Agronomy journal., vol. 108. pp. 39. Jan. 2016.

[10] Rutting T, Aronson H, and Delin S, "Efficient use of nitrogen in agriculture," Nutrient cycling in Agroecosystems., vol. 110. pp. 1-5. Jan. 2018.

[11] Chen Z, Wang H, Liu X, Lu D, Zhou J, and Li C, "Changes in soil microbial community and organic carbon fractions under short term straw return in a rice wheat cropping system," Soil and tillage usage., vol. 165. pp. 121-127. Jan. 2017.

[12] Wu H, Lai C, Zeng G, Liang J, Chen J, Xu J, "The interactions of composting and biochar and their implications for soil amendment and pollution remediations: a review," Critical reviews in Biotechnology., vol. 37. pp. 754-764. Oct. 2017.

[13] Clapp C.E, M.H.B. Hayes, and Ciavatta, "Organic wastes in soils: Biogeochemical and environmental aspects," Soil Biology., vol. 39. pp. 1239-1243. Jun. 2007.

[14] Garcia C, Hernandez T, Costa F, Ceccanti B, Masciandaro G, and Calcinai M, "Evaluation of the organic matter composition of raw and composted municipal wastes", Soil science plant nut., vol. 39. pp. 99-108. March. 1993.

[15] Hedlund A, Witter E, A.N. B.X, "Assesment of N, P, K, management by nutrient balances and flows on peri urban smallholder farms in southern Vietnam", Eur, J. Agronomy., vol. 20. pp 71-87. Nov. 2003.

[16] Makan A, and M. Moutandar, "Effect of $\mathrm{C} / \mathrm{N}$ ratio on the in-vessel composting under air pressure of organic fraction of municipal solid waste in Morocco", Mates cycles waste manag. Journal., vol. 14. pp. 241-249. Jun. 2012.

[17] Erich M.S, A.F. Plante, J.M. Fernandez, E.B. Mallory, and T. Ohno, "Effects of profile depth and management on the composition of labile and total organic matter," Soil science society., vol. 76, pp. 408-419, March. 2012.

[18] Nyakatawa E.Z, David A.M, Kozma N, James O.B, "Carbon, Nitrogen, and Phosporus dynamics in a loblollypine goat silvopasture system in the southeast USA", Agroforest System Journal., vol. 86. pp. 129-140. Oct. 2012.

[19] Schroder J, "Revisiting the agronomic benefit of manure: a correct assessment and exploitation of its fertilizer value spares the environment," Bioresour., vol. 96. pp. 253-261. Jan. 2005.

[20] Rasee D.P, J. Mulder, C. Moni, and C. Chenu, "Carbon turnover kinetics with depth in French loamy soil," Soil science society of America Joournal., vol. 70. pp. 2097-2105. Nov. 2006.

[21] Sano S, Yanai J, Kosaiki T, "Relationship between labile organic matter and nitrogen mineralization in Japanes agricultural soils with reference to land use and soil type", Soil science., vol. 52. pp. 49-60. Des. 2004.

[22] Trine A.S, and L.E Haugen, "Predicting mineral N release during decomposition of organic wastes in soil by use of the soil", Applied and Environmental Soil Science., vol. 2011. pp. 16. March. 2011. 